\title{
Evaluation of the Relationship between Retinal Nerve Fibres Layer (RNFL) Thickness in Myopia versus Hypermetropia
}

\author{
NEGM ELDIN H. ABD ALLAH, M.D.; LAMIA S. ELEWA, M.D.; \\ HAZEM M.O. MOHAMED RASHED, M.D. and ALSHIMAA A.S. ELSROUGY, M.Sc.
}

The Department of Ophthalmology, Faculty of Medicine, Ain Shams University

\begin{abstract}
Background: OCT has evolved over the past decade as one of the most important ancillary tests in ophthalmic practice. OCT makes it possible to obtain noninvasive, rapid, objective, high-resolution, cross-sectional imaging of the retina, the (RNFL) and the optic nerve head and also permits direct, realtime imaging of ocular pathology that previously could not be visualized using traditional methods.
\end{abstract}

Aim of Study: The purpose of this study is to evaluate the relationship between retinal nerve fiber layer thickness (RNFL) in myopia versus hypermetropia.

Patients and Methods: A comparative study included a total of 68 eyes divided into 45 eyes with errors of refraction and 23 emmetropic eyes in the period from March 2020 to September 2020 (Myopic eyes above -4 D, hypermetropic eyes above +4D).

Results: The results found in our study showed that there was statistically significant difference in RNFL thickness between myopic eyes, hypermetropic eyes in comparison to emmetropic eyes. RNFL thickness decreases in myopic eyes in the whole thickness and in all quadrants except in temporal quadrant, while RNFL thickness increases in hypermetropic eyes in the whole thickness and in all quadrants except in temporal quadrant.

Conclusion: Our study is comparing the peripapillary RNFL thicknesses of myopic eyes versus hyperopic eyes. We have shown that peripapillary RNFL thickness differed with refractive status of the eye being thinner in myopic eyes and thicker in hyperopic eyes.

Key Words: Retinal nerve fibres layer-Myopia-Hypermetropia.

\section{Introduction}

VARIOUS methods are being used to assess and image the retinal nerve fiber layer (RNFL), including fundus photography, scanning laser polarimetry, Heidelberger retinal tomography (HRT) and optical coherence tomography (OCT) [1] .

Correspondence to: Dr. Alshimaa A.S. Elsrougy, E-Mail: Alshimaa.adel.salaheldin@gmail.com
The OCT is a modern non-invasive imaging method which measures the peripapillary RNFL thickness in all quadrants in noncontact manner [2]. The latest spectral domain optical coherence tomography (SD-OCT) provides high axial scanning resolution (10um) which makes RNFL measurements reliable and reproducible.

Age, gender, ethnicity, axial length, size of the optic disc and refractive status of the eye are different factors which have been reported to affect the RNFL thickness [3].

The relationship of the RNFL thickness with refractive error has been extensively investigated in adults [4] and in children [4]. Different studies have shown racial differences in RNFL thickness [5].

It is therefore important to investigate whether any correlation exists between RNFL measurements and the refractive error in our population.

The current study is planned to determine the relationship between refractive error and the RNFL thickness measured by OCT in our clinical setting.

Aim of the work:

The purpose of this study is to evaluate the relationship between retinal nerve fiber layer thickness (RNFL) in myopia versus hypermetropia.

\section{Patients and Methods}

A comparative study was conducted at Ain Shams University Hospital between March 2020 to September 2020 following the approval of the research ethical committee of Ain-Shams University. 45 Eyes with errors of refraction and 23 emmetropic eyes divided into 3 groups: Group A: Myopic (above -4 D), Group B: Hypermetropic. 
(above +4D) and Group C: Emmetropic were enrolled in the study and consent form was explained to all participants and signed a written consent. Inclusion Criteria were; (1) Willingness to participate; (2) Subjects 18 years old and above will be included and divided into 3 groups: 18-30 years, 30-40 years, Above 40 years; (3) Clear optical media. Exclusion Criteria were; (1) Presence of ocular pathology; (2) Any medical disease prevents patients from positioning on the device; (3) Eyes with amblyopia; (4) History of ocular trauma; (5) Glaucoma and previous laser; or (6) Retinal therapy.

All patients were subjected to Medical \& ophthalmic history taking followed with a complete ophthalmological examination. Visual acuity: Uncorrected VA (UCVA) \& best corrected VA (BCVA) using snellen charts was examined.

All patients underwent examination of anterior segment then Fundus examination using slit lamp biomicroscopy (TOPCON series number 642338; Tokyo, Japan) \& 90 diopter lens (volk 90D) noncontact lens was used with stereoscopic slit lamp bio microscopy to evaluate the posterior segment of each subject. Both pupils of each subject were fully dilated. Posterior segment was evaluated to detect presence or absence of any abnormalities. The macular area was meticulously examined.
All patients in the study underwent OCT investigation: The OCT scanner is a fully computerized instrument that acquire and analyze cross-sectional tomograms of ocular tissue. These high depth resolution cross-sectional images of retina are obtained through noninvasive, non contact low coherence interferometry and may be useful for identifying, monitoring and quantitatively assessing macular and retinal disease.

\section{Statistical analysis:}

Data were collected, revised, coded and entered to the Statistical Package for Social Science (IBM SPSS) version 23. The quantitative data with parametric distribution were presented as mean, standard deviations and ranges. Also qualitative variables were presented as number and percentages. The $p$-value was considered significant as the following: $p$-value $>0.05$ : Non significant (NS), $p$-value $<0.05$ : Significant (S), $p$-value <0.01: Highly significant (HS).

The Following 3 cases are examples of subjects from our 3 study groups:

- Case 1 is a subject from the control group (emmetropic subjects).

- Case 2 is a subject from the myopic group.

- Case 3 is a subject from the hypermetropic group.

An OCT of 33 years old female.

Table (1): RNFL thickness in emmetropic subject.

\begin{tabular}{cccccccccc}
\hline \multicolumn{3}{c}{ Age } & \multicolumn{3}{c}{ Autorefraction } & \multicolumn{3}{c}{ RNFL thickness } \\
& SPH. & CYL & AXIS & S.E & WHOLE & INF. & SUP. & NASAL & TEMP. \\
33 & 0.00 & -0.50 & 79 & -0.25 & 116 & 140 & 170 & 73 & 80
\end{tabular}

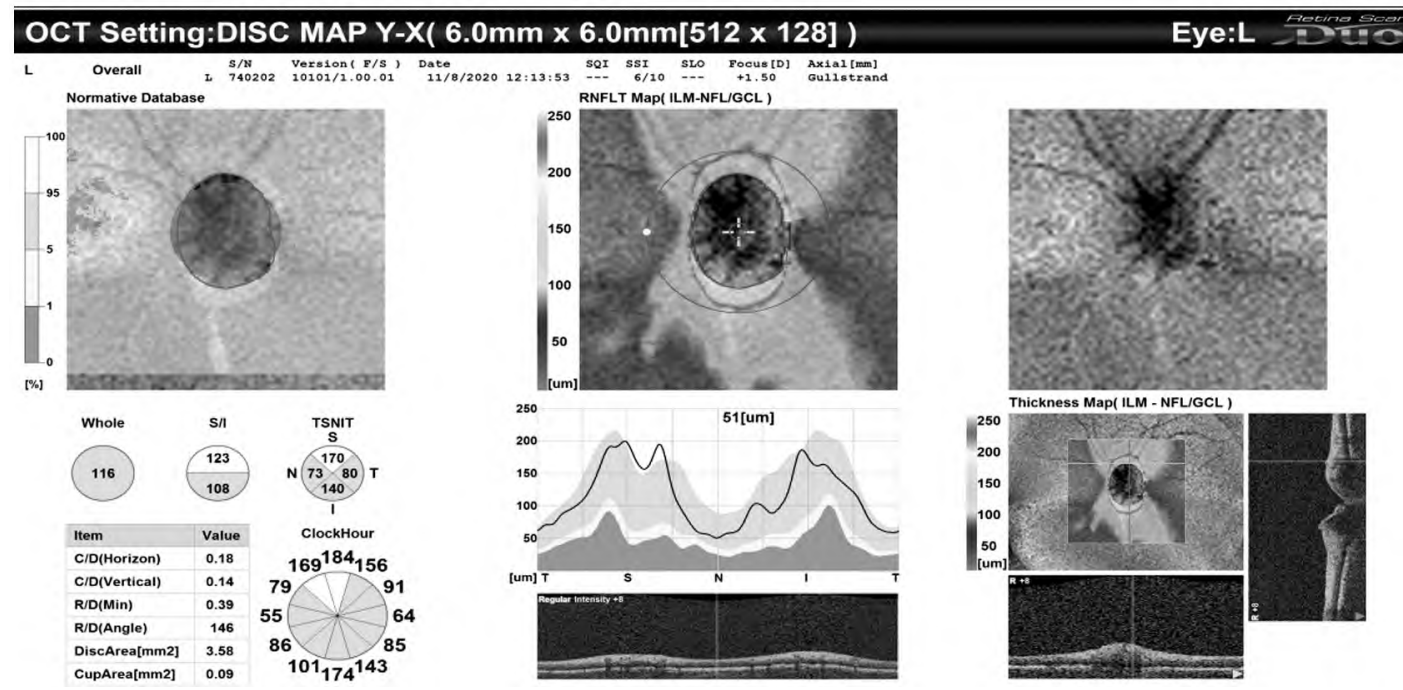

Fig. (1): OCT of RNFL thickness in emmetropic subject. 
An OCT of 18 years old female.

Table (2): RNFL thickness in myopic patient.

\begin{tabular}{|c|c|c|c|c|c|c|c|c|c|}
\hline \multirow{2}{*}{ Age } & \multicolumn{4}{|c|}{ Autorefraction } & \multicolumn{5}{|c|}{ RNFL thickness } \\
\hline & SPH. & CYL & AXIS & S.E & WHOLE & INF. & SUP. & NASAL & TEMP. \\
\hline 18 & -4.50 & -1.25 & 122 & -5.25 & 86 & 98 & 103 & 59 & 85 \\
\hline
\end{tabular}

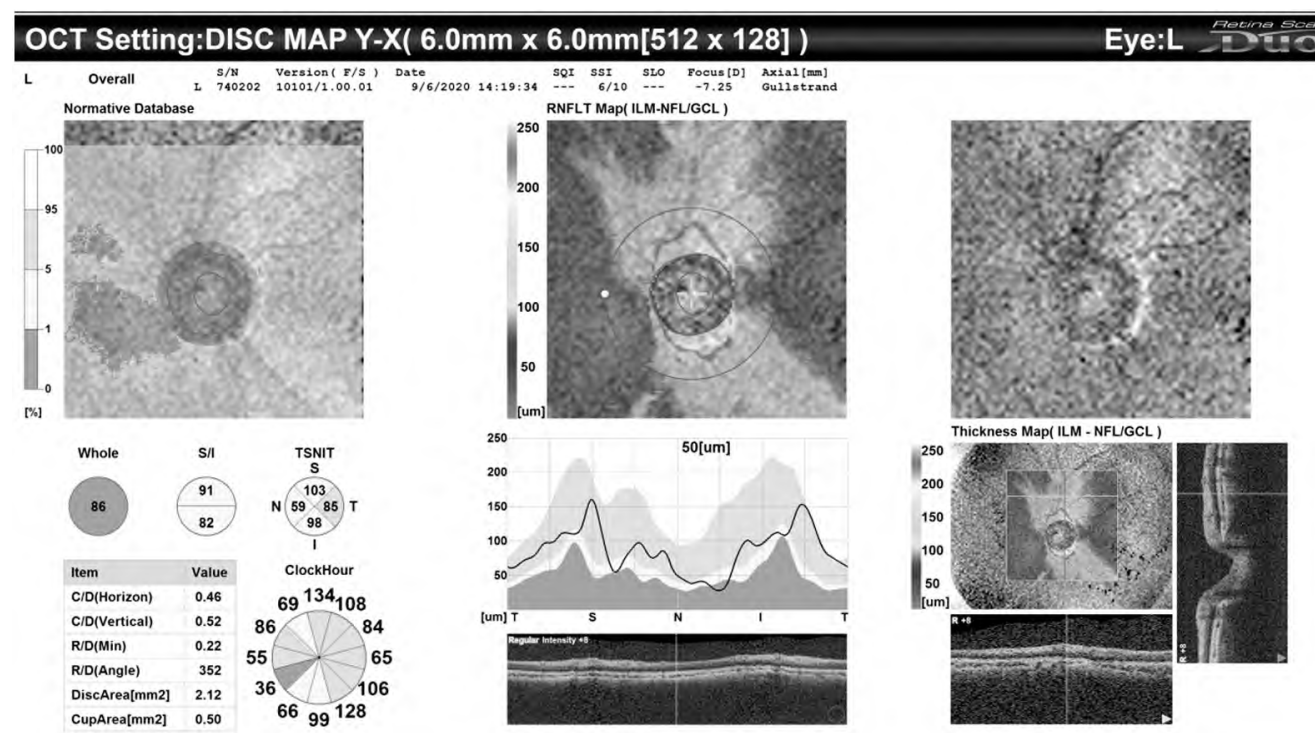

Fig. (2): OCT of RNFL thickness in myopic patient.

An OCT of 57 years old male.

Table (3): RNFL thickness in hypermetropic patients.

\begin{tabular}{|c|c|c|c|c|c|c|c|c|c|}
\hline \multirow{2}{*}{ Age } & \multicolumn{4}{|c|}{ Autorefraction } & \multicolumn{5}{|c|}{ RNFL thickness } \\
\hline & SPH. & $\overline{C Y L}$ & AXIS & S.E & WHOLE & INF. & SUP. & NASAL & TEMP. \\
\hline 57 & +4.25 & -1.00 & 71 & +3.5 & 93 & 114 & 127 & 64 & 68 \\
\hline
\end{tabular}

OCT Setting:DISC MAP Y-X(6.0mm x 6.0mm[512 x 128])

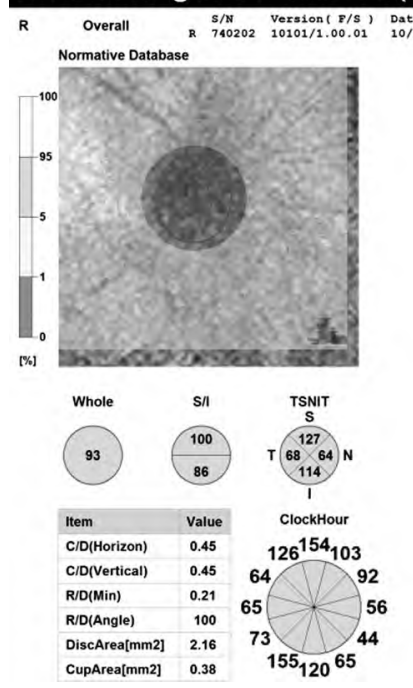

\section{Eye:R Mesting}
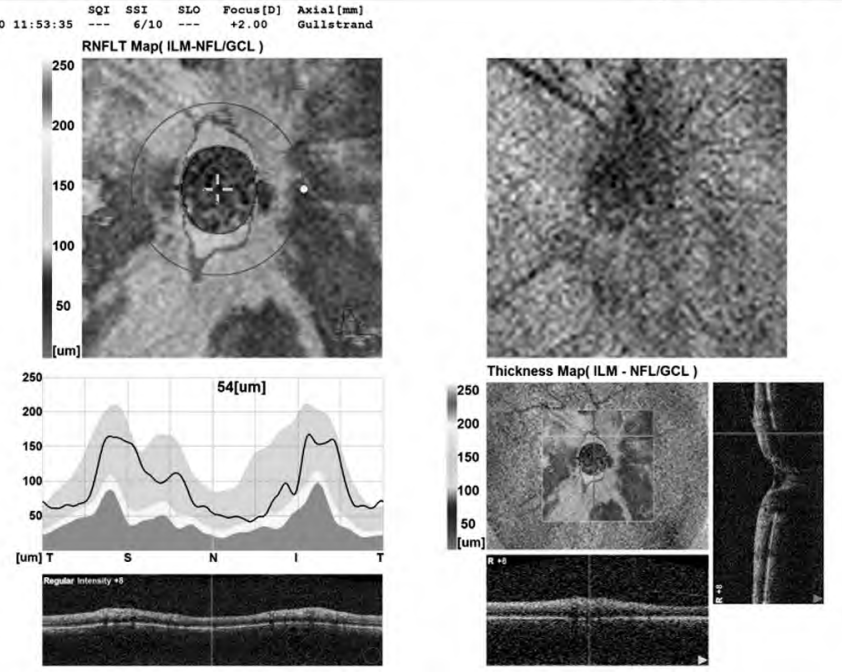

Fig. (3): OCT of RNFL thickness in hypermetropic patients. 


\section{Results}

Our study included a total of 23 eyes of control group with a mean age of 52.30 years \pm 14.77 and 45 eyes of patients group with a mean age of 53.62 years \pm 17.71 .

The mean age of emmetropic subjects was $52.304 \pm 14.766$, mean age of myopic patients was $51.520 \pm 18.782$ and mean age of hypermetropic patients was $56.250 \pm 16.348$. This is shown in Table (3) and Figs. (1-3). There was no statistically significant difference between emmetropic, myopic and hypermetropic patients regarding age and sex.

Regarding RNFL thickness findings in errors of refraction, there was statistically significant increase in whole, INF, SUP in hypermetrope than in emmetrope and myope with $p$-value $=0.004$, 0.002 and 0.007 respectively while no statistically significant difference found between them regarding nasal and temporal.

We found that there is increase in RNFL thickness in hypermetropic eyes in all quadrants except temporal quadrant with mean whole thickness range $111.20 \pm 55.17$, mean inferior quadrant thickness range $141.85 \pm 69.52$, mean superior quadrant thickness range $138.80 \pm 78.01$, mean nasal quadrant thickness range $83.10 \pm 56.70$ and mean temporal quadrant thickness range $79.05 \pm 28.27$. In myopic eyes there was decrease in RNFL thickness in all quadrants except that of temporal quadrant with mean whole thickness range $86.80 \pm 30.47$, mean inferior quadrant thickness range 101.16 \pm 39.50 , mean superior quadrant thickness range $98.04 \pm$ 39.51 , mean nasal quadrant thickness range (62.60 \pm 25.44 ) and mean temporal quadrant thickness range $79.05 \pm 28.27$.

The relation of pRNFL thickness and spherical equivalent for phakic eyes are presented in Table (6) with increasing myopic refractive error the pRNFL thickness decreases, so, we found that there is statically significant association between error of refraction and RNFL thickness.
Table (4): Demographic, characteristics and RNFL thickness parameters of all the studied subjects.

\begin{tabular}{|c|c|}
\hline & No. $=68$ \\
\hline $\begin{array}{l}\text { Sex: } \\
\quad \text { Female } \\
\text { Male }\end{array}$ & $\begin{array}{l}29(42.6 \%) \\
39(57.4 \%)\end{array}$ \\
\hline $\begin{array}{l}\text { Age: } \\
\text { Mean } \pm \text { SD } \\
\text { Range } \\
\text { Age 18-30 } \\
\text { Age 30-40 } \\
\text { Age above } 40\end{array}$ & $\begin{array}{l}53.18 \pm 16.67 \\
18-80 \\
7(10.3 \%) \\
5(7.4 \%) \\
56(82.4 \%)\end{array}$ \\
\hline $\begin{array}{l}\text { SPH: } \\
\quad \text { Mean } \pm \text { SD } \\
\quad \text { Range }\end{array}$ & $\begin{array}{l}-0.18 \pm 4.39 \\
-12-6.75\end{array}$ \\
\hline $\begin{array}{l}\text { CYL: } \\
\quad \text { Mean } \pm \mathrm{SD} \\
\quad \text { Range }\end{array}$ & $\begin{array}{l}-1.44 \pm 1.36 \\
-6-0.75\end{array}$ \\
\hline $\begin{array}{l}\text { AXIS: } \\
\quad \text { Mean } \pm \text { SD } \\
\quad \text { Range }\end{array}$ & $\begin{array}{l}88.46 \pm 38.69 \\
0-179\end{array}$ \\
\hline $\begin{array}{l}\text { S.E: } \\
\text { Mean } \pm \text { SD } \\
\text { Range } \\
\text { Emmetrope } \\
\text { Myope } \\
\text { Hypermetrope }\end{array}$ & $\begin{array}{l}-1.16 \pm 4.47 \\
-13.75-5.75 \\
23(33.8 \%) \\
25(36.8 \%) \\
20(29.4 \%)\end{array}$ \\
\hline $\begin{array}{l}\text { WHOLE: } \\
\quad \text { Mean } \pm \text { SD } \\
\quad \text { Range }\end{array}$ & $\begin{array}{l}96.71 \pm 37.55 \\
38-332\end{array}$ \\
\hline $\begin{array}{l}I N F \text { : } \\
\quad \text { Mean } \pm \text { SD } \\
\quad \text { Range }\end{array}$ & $\begin{array}{l}119.97 \pm 49.81 \\
16-410\end{array}$ \\
\hline $\begin{array}{l}\text { SUP: } \\
\quad \text { Mean } \pm \text { SD } \\
\quad \text { Range }\end{array}$ & $\begin{array}{l}114.47 \pm 53.01 \\
12-456\end{array}$ \\
\hline $\begin{array}{l}\text { NASAL: } \\
\quad \text { Mean } \pm \text { SD } \\
\quad \text { Range }\end{array}$ & $\begin{array}{l}72.37 \pm 37.84 \\
11-300\end{array}$ \\
\hline $\begin{array}{l}\text { TEMP: } \\
\quad \text { Mean } \pm \text { SD } \\
\quad \text { Range }\end{array}$ & $\begin{array}{l}76.50 \pm 35.70 \\
26-299\end{array}$ \\
\hline $\begin{array}{l}\text { IOP: } \\
\quad \text { Mean } \pm \mathrm{SD} \\
\quad \text { Range }\end{array}$ & $\begin{array}{l}13.66 \pm 2.30 \\
10-21\end{array}$ \\
\hline
\end{tabular}

Table (5): Comparison between control group and patients group regarding age and sex of the studied patients.

\begin{tabular}{|c|c|c|c|c|c|}
\hline & $\begin{array}{c}\text { Control group } \\
\text { No. }=23 \\
\end{array}$ & $\begin{array}{c}\text { Patients group } \\
\text { No. }=45\end{array}$ & Test value & $p$-value & Sig. \\
\hline $\begin{array}{l}\text { Age: } \\
\quad \text { Mean } \pm \text { SD } \\
\quad \text { Range }\end{array}$ & $\begin{array}{l}52.30 \pm 14.77 \\
28-80\end{array}$ & $\begin{array}{l}53.62 \pm 17.71 \\
18-80\end{array}$ & $-0.306 \bullet$ & 0.760 & NS \\
\hline $\begin{array}{l}\text { Age } 18-29 \\
\text { Age } 30-40 \\
\text { Age above } 40\end{array}$ & $\begin{array}{l}1(4.3 \%) \\
5(21.7 \%) \\
17(73.9 \%)\end{array}$ & $\begin{array}{l}6(13.3 \%) \\
5(11.1 \%) \\
34(75.6 \%)\end{array}$ & $2.368 *$ & 0.306 & NS \\
\hline $\begin{array}{l}\text { Sex: } \\
\quad \text { Female } \\
\text { Male }\end{array}$ & $\begin{array}{l}8(34.8 \%) \\
15(65.2 \%)\end{array}$ & $\begin{array}{l}21(46.7 \%) \\
24(53.3 \%)\end{array}$ & $0.879 *$ & 0.349 & NS \\
\hline
\end{tabular}

$p$-value $>0.05$ : Non significant (NS). $\quad p$-value $<0.05$ : Significant (S). $\quad p$-value $<0.01$ : Highly significant (HS).

*:Chi-square test. $\quad \because$ : Independent $t$-test. 
The previous table shows that there was no statistically significant difference found between

control group and patients group regarding age and sex.

Table (6): Comparison between emmetrope, myope and hypermetrope groups regarding age and sex of the studied patients.

\begin{tabular}{|c|c|c|c|c|c|c|}
\hline & $\begin{array}{c}\text { Emmetrope } \\
\text { No. }=23\end{array}$ & $\begin{array}{c}\text { Myope } \\
\text { No. }=25\end{array}$ & $\begin{array}{c}\text { Hypermetrope } \\
\text { No. }=20\end{array}$ & Test value & $p$-value & Sig. \\
\hline \multicolumn{7}{|l|}{ Age: } \\
\hline Mean \pm SD & $52.304 \pm 14.766$ & $51.520 \pm 18.782$ & $56.250 \pm 16.348$ & $0.487 \bullet$ & 0.616 & NS \\
\hline Range & $28-80$ & $18-72$ & $18-80$ & & & \\
\hline Age $18-30$ & $1(4.3 \%)$ & $4(16.0 \%)$ & $2(10.0 \%)$ & $4.099 *$ & 0.393 & NS \\
\hline Age $30-40$ & $5(21.7 \%)$ & $4(16.0 \%)$ & $1(5.0 \%)$ & & & \\
\hline Age above 40 & $17(73.9 \%)$ & $17(68.0 \%)$ & $17(85.0 \%)$ & & & \\
\hline \multicolumn{7}{|l|}{ Sex: } \\
\hline Female & $8(34.8 \%)$ & $11(44.0 \%)$ & $10(50.0 \%)$ & $1.042 *$ & 0.594 & NS \\
\hline Male & $15(65.2 \%)$ & $14(56.0 \%)$ & $10(50.0 \%)$ & & & \\
\hline
\end{tabular}

$p$-value $>0.05$ : Non significant (NS). $p$-value $<0.05$ : Significant (S). $\quad p$-value $<0.01$ : Highly significant (HS).

*:Chi-square test. $\bullet$ : One way ANOVA test.

The previous table shows that there was no statistically significant difference found between emmetropic subjects, myopic patients and hypermetropic patients regarding age and sex.

Table (7): Relation between age of the studied patients and RNFL thickness in the whole and 4 quadrants.

\begin{tabular}{|c|c|c|c|c|c|c|}
\hline & $\begin{array}{c}\text { Age } 18-29 \\
\text { No. }=6\end{array}$ & $\begin{array}{l}\text { Age } 30-40 \\
\text { No. }=5\end{array}$ & $\begin{array}{c}\text { Age above } 40 \\
\text { No. }=34\end{array}$ & Test value & $p$-value & Sig. \\
\hline \multicolumn{7}{|l|}{ Whole: } \\
\hline Mean \pm SD & $98.17 \pm 16.07$ & $77.00 \pm 10.51$ & $100.59 \pm 50.02$ & $5.230 \ddagger$ & 0.073 & NS \\
\hline Range & $78-123$ & $61-87$ & $38-332$ & & & \\
\hline \multicolumn{7}{|l|}{ Inferior: } \\
\hline Mean \pm SD & $126.00 \pm 22.36$ & $73.80 \pm 33.87$ & $124.74 \pm 62.51$ & $6.796 \ddagger$ & 0.033 & S \\
\hline Range & $98-163$ & $16-100$ & $54-410$ & & & \\
\hline \multicolumn{7}{|l|}{ Superior: } \\
\hline Mean \pm SD & $118.33 \pm 26.14$ & $82.20 \pm 19.40$ & $120.76 \pm 69.65$ & $4.991 \ddagger$ & 0.082 & NS \\
\hline Range & $73-142$ & $63-110$ & $12-456$ & & & \\
\hline \multicolumn{7}{|l|}{ Nasal: } \\
\hline Mean \pm SD & $81.50 \pm 29.36$ & $54.40 \pm 16.62$ & $72.53 \pm 47.28$ & $2.519 \ddagger$ & 0.284 & NS \\
\hline Range & $52-121$ & $32-74$ & $11-300$ & & & \\
\hline \multicolumn{7}{|l|}{ Temporal: } \\
\hline Mean \pm SD & $67.17 \pm 18.08$ & $76.00 \pm 33.81$ & $80.29 \pm 46.39$ & $0.109 \ddagger$ & 0.947 & NS \\
\hline Range & $36-85$ & $43-133$ & $26-299$ & & & \\
\hline
\end{tabular}

$p$-value $>0.05$ : Non significant (NS). $\quad p$-value <0.05: Significant (S). $\quad p$-value <0.01: Highly significant (HS)

$\bullet:$ Independent $t$-test. $\$$ : Mann whitney test.

The previous table shows that there was no statistically significant difference found between the three age groups regarding RNFL thickness except INF quardant as there was statistically significant difference found.

The previous table shows that there was statistically significant increase in whole, INF, SUP in hypermetrope and in emmetrope than myope with $p$-value $=0.004,0.002$ and 0.007 respectively while no statistically significant difference found between them regarding nasal and temporal.

The previous table shows that there was statistically significant positive correlation found between S.E and whole, INF, SUP and nasal while no statistically significant correlation found between S.E and temporal and IOP. 
Table (8): Comparison between emmetrope, myope and hypermetrope groups regarding RNFL thickness in the whole and 4 quadrants.

\begin{tabular}{|c|c|c|c|c|c|c|}
\hline & $\begin{array}{c}\text { Emmetrope } \\
\text { No. }=23\end{array}$ & $\begin{array}{c}\text { Myope } \\
\text { No. }=25\end{array}$ & $\begin{array}{c}\text { Hypermetrope } \\
\text { No. }=20\end{array}$ & Test value $\ddagger$ & $p$-value & Sig. \\
\hline \multicolumn{7}{|l|}{ Whole: } \\
\hline Mean \pm SD & $94.87 \pm 18.64$ & $86.80 \pm 30.47$ & $111.20 \pm 55.17$ & 11.299 & 0.004 & HS \\
\hline Range & $55-124$ & $38-215$ & $50-332$ & & & \\
\hline \multicolumn{7}{|l|}{ Inferior: } \\
\hline Mean \pm SD & $121.39 \pm 28.99$ & $101.16 \pm 39.50$ & $141.85 \pm 69.52$ & 12.645 & 0.002 & HS \\
\hline Range & $54-170$ & $16-235$ & $54-410$ & & & \\
\hline \multicolumn{7}{|l|}{ Superior: } \\
\hline Mean \pm SD & $111.17 \pm 27.25$ & $98.04 \pm 39.51$ & $138.80 \pm 78.01$ & 10.004 & 0.007 & HS \\
\hline Range & $61-170$ & $12-222$ & $66-456$ & & & \\
\hline \multicolumn{7}{|l|}{ Nasal: } \\
\hline Mean \pm SD & $73.65 \pm 25.73$ & $62.60 \pm 25.44$ & $83.10 \pm 56.70$ & 5.059 & 0.080 & NS \\
\hline Range & $46-161$ & $19-153$ & $11-300$ & & & \\
\hline \multicolumn{7}{|l|}{ Temporal: } \\
\hline Mean \pm SD & $73.43 \pm 17.77$ & $77.28 \pm 51.20$ & $79.05 \pm 28.27$ & 1.612 & 0.447 & NS \\
\hline Range & $44-123$ & $26-299$ & $36-162$ & & & \\
\hline \multicolumn{7}{|c|}{ Post Hoc Analysis } \\
\hline & Parameters & $p_{1}$ & $p_{2}$ & $p_{3}$ & & \\
\hline & Whole & 0.450 & 0.151 & 0.030 & & \\
\hline & Inferior & 0.147 & 0.165 & 0.006 & & \\
\hline & Superior & 0.377 & 0.081 & 0.010 & & \\
\hline
\end{tabular}

$p$-value $>0.05$ : Non significant (NS), $p$-value <0.05: Significant (S), $p$-value< 0.01: Highly significant (HS), $\ddagger$ : Kruskal Wallis test. $p$ 1: Emmetrope vs Myope. $\quad p 2$ : Emmetrope vs Hypermetrope. $\quad p 3$ : Myope vs Hypermetrope.

Table (9): Correlation between spherical equivalent (S.E) and RNFL thickness and IOP.

\begin{tabular}{llc}
\hline & \multicolumn{2}{c}{ S.E } \\
\cline { 2 - 3 } & \multicolumn{1}{c}{$r$} & $p$-value \\
\hline Whole & $0.320^{* *}$ & 0.008 \\
Inferior & $0.427^{* *}$ & 0.000 \\
Superior & $0.380^{* *}$ & 0.001 \\
Nasal & $0.292^{*}$ & 0.016 \\
Temporal & 0.039 & 0.749 \\
IOP & 0.064 & 0.605 \\
\hline
\end{tabular}

\section{Discussion}

We found that in comparison with emmetropic eyes; the mean RNFL is thinner in myopes (superior, inferior and nasal quadrants) with no changes in temporal quadrant while in hyperopes there was an increase in the mean RNFL thickness in (inferior, superior and nasal quadrants) with no changes in temporal quadrant.

Our study showed positive correlation between spherical equivalent (s.e) mean range $(-1.16 \pm 4.47)$ and peripapillary RNFL thickness, i.e. as the s.e decreases, there was thinning of RNFL in most cases.
Spoorthy et al. [8] in 2020 who conducted the study on 90 cases, 36 (40\%) myopes, 24 (26.66\%) hyperopes and $30(33.33 \%)$ emmetropes, with mean RNFL thickness in myopes $(90.86 \pm 10.50$ $\mathrm{mm})$, in hyperopes $(116 \pm 3.6 \mathrm{~mm})$ and emmetropes $(120 \pm 4.3 \mathrm{~mm})$. Mean RNFL is thinner in myopes than in emmetropes with superior and inferior quadrants thinning but in contrast to our study there was no mean RNFL thickness changes in hyperopes when compared to emmetropes.

Lee et al. [9] in 2015 who conducted the study on 201 subjects eligible for the study. There were 98 female and 103 male subjects; all were of Chinese ethnicity. There were $67(33.1 \%)$ myopic eyes, 61 (30.1\%) emmetropic eyes, and 73 (36.3\%) hyperopic eyes.

The association between myopia and a thinner RNFL has been well documented in adults although there are others who have reported differently.

We found that the mean global RNFL in the myopic group was still significantly thinner than the other 2 groups (both $p 0.0001$ ), but there was no significant difference in RNFL thickness between the emmetropic and hyperopic groups $(p>0.05)$. This suggested that the thinner RNFL in 
the myopic group was attributed to both an older age as well as refraction related factors. On the contrary, hyperopia did not confer a thicker RNFL as compared with those with emmetropia.

Öner et al. [10] in 2013 found that Mean peripapillary RNFL was thinner in the myopic group than in the control group $(96.9 \pm 11.9)$. The RNFLs were thinner in the superior $(118.1 \pm 20.4)$, inferior $(122.6 \pm 16.5)$ and temporal $(62.8 \pm 18.7)$ quadrants; whereas in contrast to our study it was thicker in the nasal quadrant $(82.2 \pm 22.2)$. Although the RNFL was thicker in the nasal quadrant $(82.2 \pm 19.0)$ in the hyperopic group; and in contrast to our study they have found no difference between the hyperopic and control groups regarding the mean peripapillary RNFL thickness $(98.4 \pm 10.2)$.

Rauscher et al. [11] found a significant strong association between axial length and the mean peripapillary RNFL thickness in superior and inferior quadrants but less strong relationship was found between SE and RNFL thickness of the both quadrants in myopic patients. That study included 27 patients and we believe that the sample size was too small to give a reliable result. In another study including 115 eyes showed that there were significant correlations between RNFL thicknesses (inferior, superior and nasal quadrant) and SE.

Kim et al. [12] demonstrated that the eyes with high myopia had significantly thinner RNFLs in the non-temporal sectors compared with the eyes with low myopia, and they showed a significantly thicker RNFL in the temporal quadrant.

\section{References}

1- OWNSEND K.A., WOLLSTEIN G. and SCHUMAN J.S. Imaging of the retinal nerve fiber layer for glaucoma. $\mathrm{Br}$. J. Ophthalmol., 93: 139-43, 2009.

2- SOWMYA V., VENKATARAMANAN V.R. and VISHNU K.P.: Analysis of retinal nerve fiber layer thickness using optical coherence tomography in normal South Indian population. Muller J. Med. Sci. Res., 5: 5-10, 2014.
3- NAGAI-KUSUHARA A., NAKAMURA M., FUJIOKA M., TATSUMI Y. and NEGI A.: Association of retinal nerve fibre layer thickness measured by confocal scanning laser ophthalmoscopy and optical coherence tomography with disc size and axial length. Br. J. Ophthalmol., 92: 186-90, 2008

4- SOWMYA V., VENKATARAMANAN V.R. and PRASAD V.: Effect of Refractive Status and Axial Length on Peripapillary Retinal Nerve Fibre Layer Thickness: An Analysis Using 3D OCT. J. Clin. Diagn. Res., 9: NC014, 2015.

5- World Health Organization: What is a refractive error? 2013. http:// www.who.int/features/qa/ 45/en/. accessed May 3, 2014.

6- ALASIL T., WANG K., KEANE P.A., et al.: Analysis of normal retinal nerve fiber layer thickness by age, sex, and race using spectral domain optical coherence tomography. J. Glaucoma., 22: 532-541, 2013.

7- CARPINETO P., CIANCAGLINI M., ZUPPARDI E., FALCONIO G., DORONZO E. and MASTROPASQUA L.: Reliability of nerve fiber layer thickness measurements using optical coherence tomography in normal and glaucomatous eyes. Ophthalmology, 110: 190-95, 2003.

8- SPOORTHY S. and SHRUTHI K.P.: Peripapillary retinal nerve fibre layer thickness variation in refractive errors among adults. Indian J. Clin. Exp. Ophthalmol., 6 (3): 410-412, 2020.

9- LEE J.W., WOO T.T., YAU G.S., et al.: Cross-sectional study of the retinal nerve fiber layer thickness at 7 years after an acute episode of unilateral primary acute angle closure. Medicine (Baltimore), 94: e391, 2015.

10- ÖNER V., AYKUT V., TAS M., ALAKUS M.F. and ISCAN Y.: Effect of refractive status on peripapillary retinal nerve fibre layer thickness: A study by RTVue spectral domain optical coherence tomography. British Journal of Ophthalmology, 97 (1): 75-9, 2013.

11- RAUSCHER F.M., SEKHON N., FEUER W.J. and BUDENZ D.L.: Myopia affects retinal nerve fiber layer measurements as determined by optical coherence tomography. Journal of Glaucoma., 18 (7): 501, 2009.

12- KIM M.J., LEE E.J. and KIM T.W.: Peripapillary retina nerve fibre layer thickness profile in subjects with myopia measured using the Stratus optical coherence tomography. Br. J. Ophthalmol., 94: 115-20, 2010. 


\section{تقييم العلاقة بين سماكة طبقة ألياف الشبكية العصبية

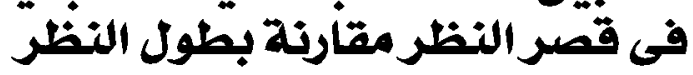 بواسطة التصوير المقطعى للشبكية}

المقدمة: لقد تطود التصوير المقطعى اللشبكية على مدار العقد الماضيى كواحد من أهم الاختبارات المساعدة في ممارسة طب العيون.

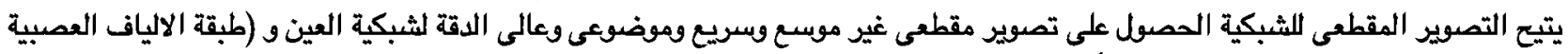
بالشبكية) والعصب البصرى ويسمح أيضاً بالتصوير المباشر لأمراض العين التى لم يكن من الممكن فى السابق تصويرها باستخدام الطرق التقليدية.

الهدف من البحث: الغرض من هذه الدراسة هو تقييم العلاقة بين سمك طبقة ألياف الشبكية العصبية فى قصر النظر مقارنة بطول النظر بواسطة التصوير المقطعى الشبكية.

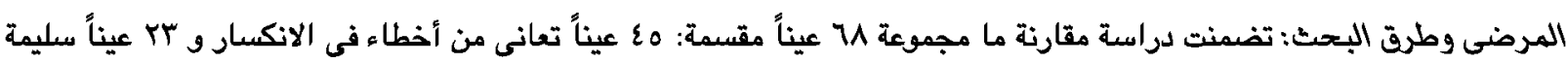

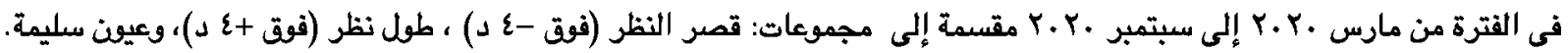
النتائج: أظهرت النتائج التى تم العثد عليها فى دراستتا أن هناك فروق ذات دلالة إحصائية فى سمك طبقة الألياف العصبية بالشبكية بين العيفن ذات قصر النظر واليیفن ذات طول النظر مقارنة بالعيون السليمة.

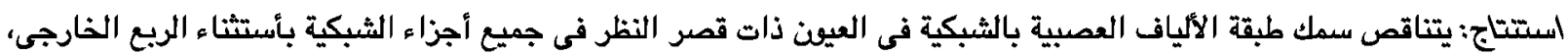
بينما يزيد سمك طبقة الألياف العصبية بالشبكية فى العيف ذات طول النظر فى جميع الأجزاء بأستثناء الربع الخارجى. 